INTERNATIONAL JOURNAL OF RESEARCHES IN BIOSCIENCES, AGRICULTURE AND TECHNOLOGY

(C) VISHWASHANTI MULTIPURPOSE SOCIETY (Global Peace Multipurpose Society) R. No. MH-659/13(N) www.vmsindia.org

\title{
STATISTICAL ANALYSIS OF FUEL CONSUMPTION PATTERN IN KITCHEN BY HOUSEHOLDS IN RURAL AREA OF SANGLI DISTRICT (MAHARASHTRA-INDIA)
}

\author{
R. R. Kumbhar and U. H. Pawar \\ Shri Swami Vivekanand Shikshan Sanstha, Kolhapur Sanchlit \\ Padmbhushan Dr. Vasantaraodada Patil Mahavidylaya, Tasgaon, Dist-Sangli \\ (Maharashtra-India)
}

\begin{abstract}
:
The availability of energy is an important determinant of the quality of life in human settlements. A study has been carried out to identify the fuel consumption pattern in rural areas on pilot basis in the villages in Sangli District of Maharashtra state in India. The Eastern part of the District is known as the drought prone area and the agricultural pattern is completely depending on the rainy season. The study reveals that the present level of use of fuel wood by households $(509.5 \mathrm{~kg} /$ month) is continuing despite the fact that other fuels like kerosene $(3.47$ Lit/month), Liquid Petroleum Gas (LPG) $(7.22 \mathrm{Kg} / \mathrm{month})$ are also being used. The study also revealed that rural households use fire wood, cow-dung, leaves \& twigs, branches, straw as biomass energy mainly for cooking. It was found that rural households collect of biomass from their own homestead and agricultural lands. Per capita per day fuel wood consumption reveals that due to improper distribution of the LPG and kerosene there is excess use of fuel wood which tends to de-forestation in the rural area of the District. It is concluded from study that consumption of LPG in Kitchen by households is proportional to the income while tendency to use Kerosene in Kitchen by households, on an average, is almost same for different income groups. The study is helpful to formulate policies and support tools to take into account the future challenges for demand of fuel resources, their sustainable utilization, promotion, and development.
\end{abstract}

Keywords: Households, Consumption, Fuel, Liquid Petroleum Gas (LPG), Kerosene.

\section{Introduction:}

In the household sector, fuels are consumed for cooking, lighting, heating water for bathing and washing clothes and heating/cooling rooms. The major fuels consumed are commercial fuels like kerosene, LPG, soft coke/coal, electricity and the noncommercial fuels such as fuel wood (firewood, twigs, sawdust and wood shavings), dung cakes, crop waste, and charcoal and gobar gas. From the ancient time human beings are uses different types of fuels for domestic purpose but at that time most preferable fuel type is wood. Now-a-day's human beings have a wider choice and greater accessibility to modern commercial fuels, electricity, solar equipments' and therefore they have greater potential for fuel switching. But this picture is not same in whole part of the country like India, where almost rural population is $68.70 \%$ in 2011 , according to the World Bank. To understand the change in the consumption pattern of domestic fuels by Indian households it is necessary to conduct National Survey.

In rural area many households still depend on wood as a primary fuel for domestic purpose because their choices are constrained by lack of access to more commercial fuels and markets for energy using equipments and appliances. Often, the choice of fuel is determined more by local availability and transaction and opportunity costs involved in gathering the fuel (mostly wood) rather than by household budget constraints, prices and costs.

Despite a major shift away from the use of biomass fuels towards commercial fossil fuels and electricity over the last couple of decades, in rural areas, there are still many poor Indian households who rely on firewood as their primary source of cooking energy. However, there appears to be a clear order of preference and progression in terms of the switching and substitution behavior of households in their choice of cooking fuel. While all households do not necessarily switch completely or, in other words, terminate the use of one fuel when taking up the use of another, the general observation is that LPG is the preferred option for those who can afford it and have access to it.

Very limited study has been carried out solely in the domestic level of the energy consumption by the households. The Sangli District of Maharashtra state is the area under study. The main purpose of the paper is, to know the what kind of priority pattern people gives to the different fuel, for use of cooking as well as for water heating for bath.

\section{Material Methods:}

Sangli district is located between $16^{\circ} 45^{\prime}$ \& 17033' N latitudes and 73042' \& 75040' E longitudes occupying an area of $8572 \mathrm{Km}^{2}$ of southern Maharashtra. Administratively, it consists of ten tahsils (Fig -1) and the region 
presents diversified physiographic with hilly region dominated by leeward slopes of Western Ghats in the west and alternate valleys and ridges culminated gradually into plateau in the east. The soils vary from laterite patches in the west through deep medium-black alluvial of the river plains in the center and poor gray soils in the east. The monsoon climate dominates the region with little variation in heat and cold. The region receives rainfall mainly from south-west monsoon averaging between $2000 \mathrm{~m}$. m. in the west to $500 \mathrm{~m}$. m. in the eastern part, a fairly rain shadow belt, which has experienced frequent drought conditions.

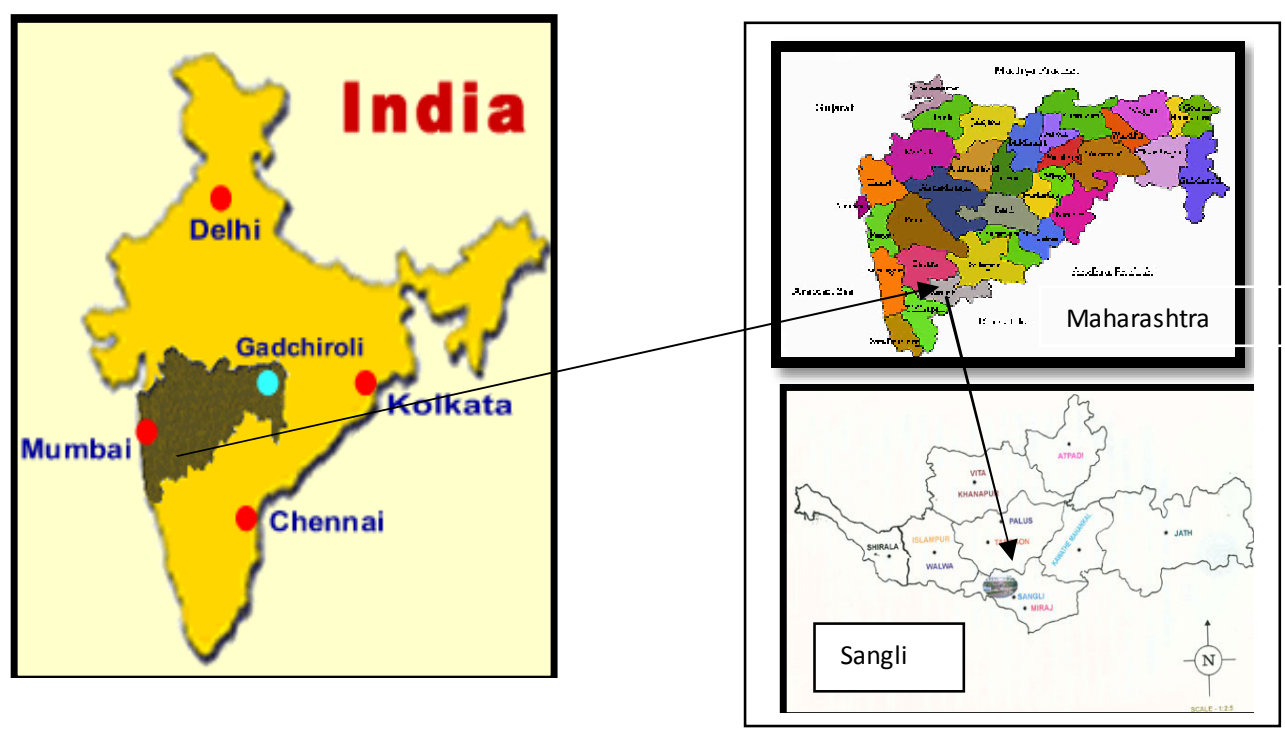

Figure. 1- Sangli District.

Due to constraints of time researcher has conducted a pilot sample survey and collected data from villages belongs to Tasgaon tahasil in Sangli District through a questionnaire. Here a sample of 121 households is selected from three small villages in the district having total 2424 households by convenience sampling technique. The following different statistical tools were used to analyses, present and interpretation of the collected data.

\section{Descriptive Statistics:}

Table.1: Average consumption of fuels

\begin{tabular}{|l|l|l|l|l|}
\hline Variable & User & $\begin{array}{l}\text { Expected } \\
\text { User }\end{array}$ & $\begin{array}{l}\text { Average } \\
\text { consumption/Month }\end{array}$ & $\begin{array}{l}\text { Standard } \\
\text { deviation }\end{array}$ \\
\hline LPG & 81 & 1678 & $7.215659 \mathrm{Kg}$ & $3.566784 \mathrm{Kg}$. \\
\hline KEROSENE & 79 & 1637 & $3.478873 \mathrm{Lt}$. & $1.903824 \mathrm{Lt}$. \\
\hline WOOD & 21 & 2238 & $509.4736 \mathrm{Kg}$. & $2.258233 \mathrm{Kg}$. \\
\hline BIOGAS & 3 & 62 & - & - \\
\hline
\end{tabular}

Table.2: Per capita fuel consumption according to age group and sex wise.

\begin{tabular}{|l|l|l|l|}
\hline Gender & Age & LPG(Kg.) & KEROSENE(Lt.) \\
\hline \multirow{4}{*}{ Male } & $>59$ & 0.2005 & 0.2069 \\
\cline { 2 - 5 } & $18<$ age $\leq 59$ & 0.2817 & 0.2785 \\
\cline { 2 - 5 } & $5<$ age $\leq 18$ & 0.0718 & 0.0734 \\
\cline { 2 - 5 } & $1<$ age $\leq 5$ & 0.0344 & 0.0347 \\
\cline { 2 - 5 } & $\leq 1$ & 0.0149 & 0.0149 \\
\hline \multirow{5}{*}{ Female } & $>59$ & 0.1986 & 0.2045 \\
\cline { 2 - 5 } & $18<$ age $\leq 59$ & 0.1884 & 0.1897 \\
\cline { 2 - 5 } & $5<$ age $\leq 18$ & 0.0688 & 0.0706 \\
\cline { 2 - 4 } & $1<$ age $\leq 5$ & 0.0299 & 0.027 \\
\cline { 2 - 4 } & $\leq 1$ & 0.0253 & 0.0245 \\
\hline
\end{tabular}

Graphical Representation: Pie chart, Bar diagram, Multiple bar diagram.

Descriptive Statistics: Mean and Standard Deviation.

Per Capita Fuel Consumption (PCFC):

$P C F C=\left(\frac{F C}{P}\right)$;

Where $\mathrm{FC}=\mathrm{Fuel}$ consumption in $\mathrm{Kg} /$ day/liter. $\mathrm{P}=$ Number of adults equivalents for whom food was cooked. 


\section{Result and Discussion:}

Pie diagrams of Consumption pattern of fuels:

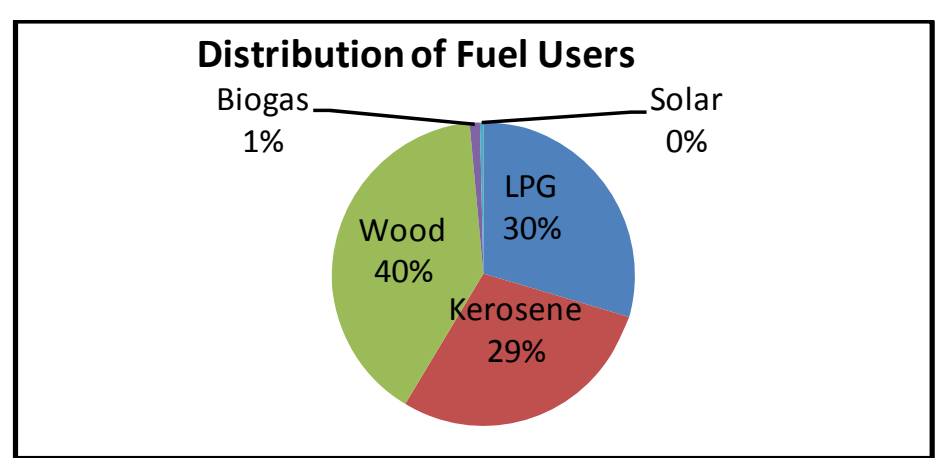

Table.3: Fuel Pattern and Expected
Users
\begin{tabular}{|l|c|c|}
\hline Fuel & No.Users & $\begin{array}{c}\text { Expected } \\
\text { Users }\end{array}$ \\
\hline LPG & 81 & 1678 \\
\hline KEROSENE & 79 & 1637 \\
\hline WOOD & 108 & 2238 \\
\hline BIOGAS & 3 & 62 \\
\hline
\end{tabular}

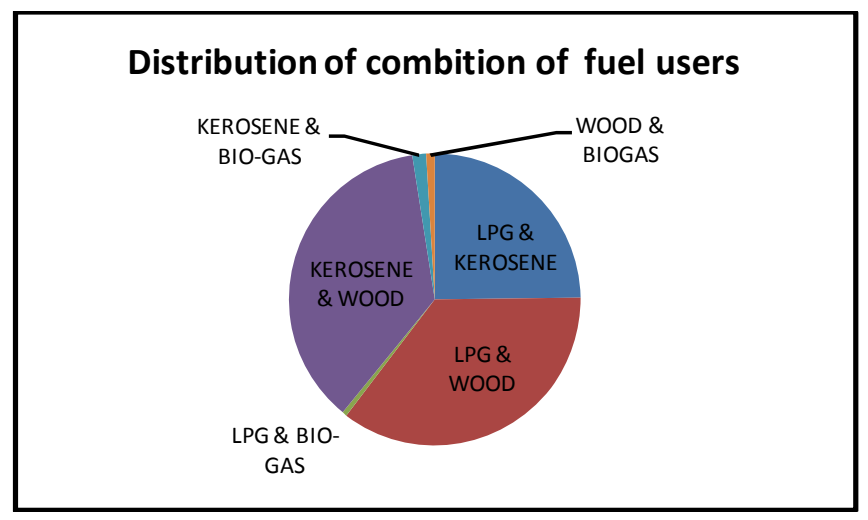

\begin{tabular}{||l|c|}
\hline \multicolumn{2}{|l|}{ Table.4: Distribution of Combustion of Fuel Users } \\
\hline Fuel Type & $\begin{array}{c}\text { Number Of } \\
\text { Households }\end{array}$ \\
\hline LPG \& KEROSENE & 50 \\
\hline LPG \& WOOD & 72 \\
\hline LPG \& BIO GAS & 1 \\
\hline KEROSENE \& WOOD & 74 \\
\hline KEROSENE \& BIOGAS & 3 \\
\hline WOOD \& BIOGAS & 2 \\
\hline
\end{tabular}

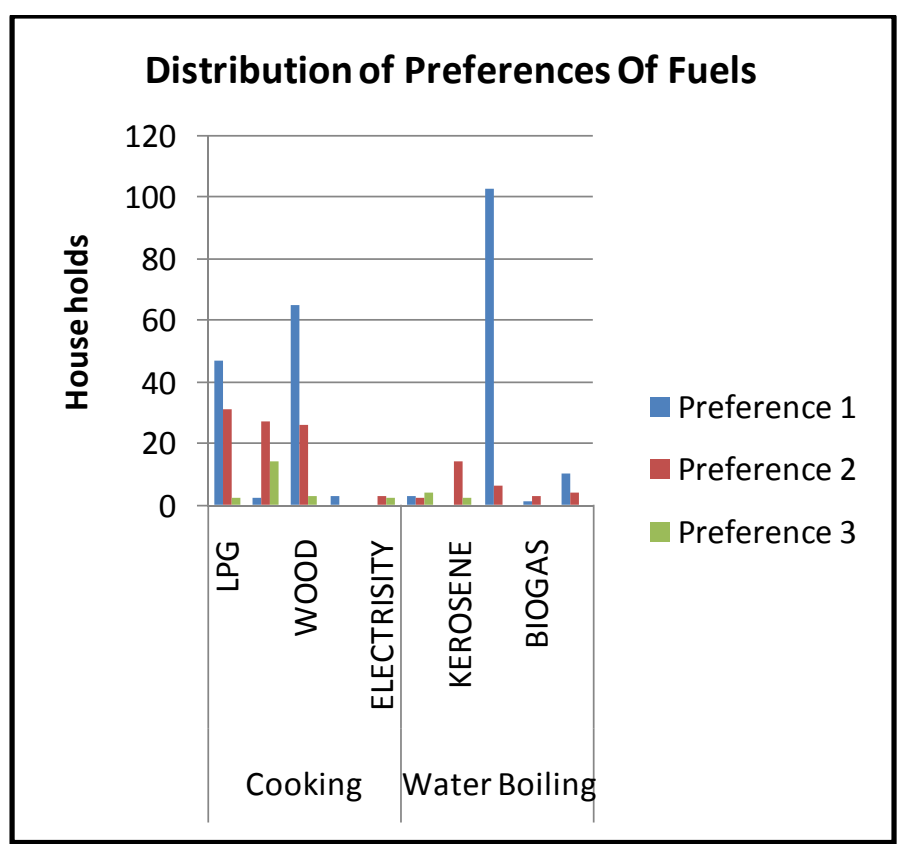

\begin{tabular}{|c|c|c|c|c|}
\hline \multicolumn{5}{|c|}{$\begin{array}{l}\text { Table.5: Preferences of Fuels for Cooking and Water } \\
\text { boiling }\end{array}$} \\
\hline \multirow{2}{*}{ Purpose } & \multirow{2}{*}{ Fuel Type } & \multicolumn{3}{|c|}{ Preference } \\
\hline & & 1 & 2 & 3 \\
\hline \multirow{5}{*}{ Cooking } & LPG & 47 & 31 & 2 \\
\hline & KEROSENE & 2 & 27 & 14 \\
\hline & WOOD & 65 & 26 & 3 \\
\hline & BIOGAS & 3 & 0 & 0 \\
\hline & ELECTRISITY & 0 & 3 & 2 \\
\hline \multirow{5}{*}{$\begin{array}{l}\text { Water } \\
\text { Boiling }\end{array}$} & LPG & 3 & 2 & 4 \\
\hline & KEROSENE & 0 & 14 & 2 \\
\hline & WOOD & 103 & 6 & 0 \\
\hline & BIOGAS & 1 & 3 & 0 \\
\hline & ELECTRISITY & 10 & 4 & 0 \\
\hline
\end{tabular}




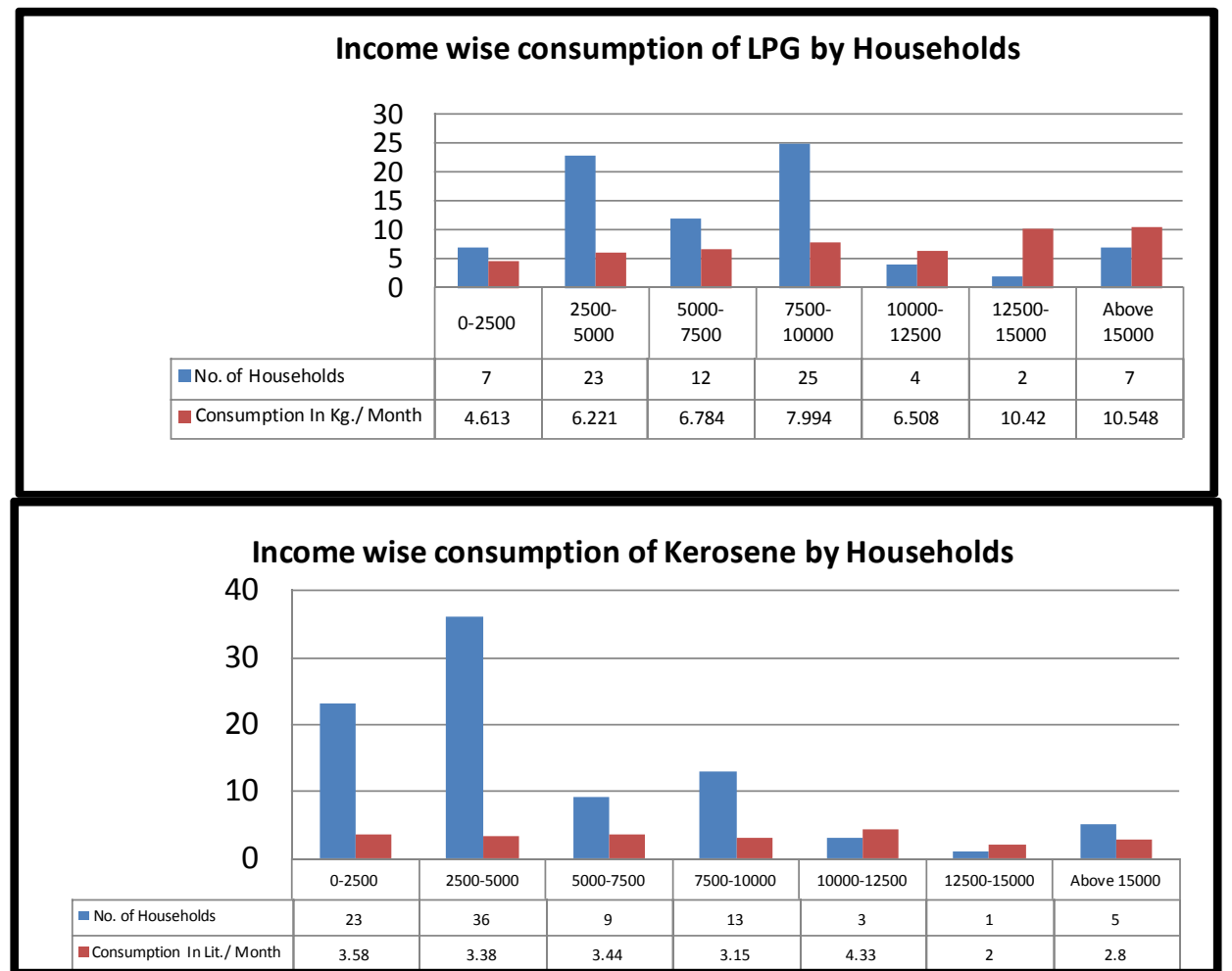

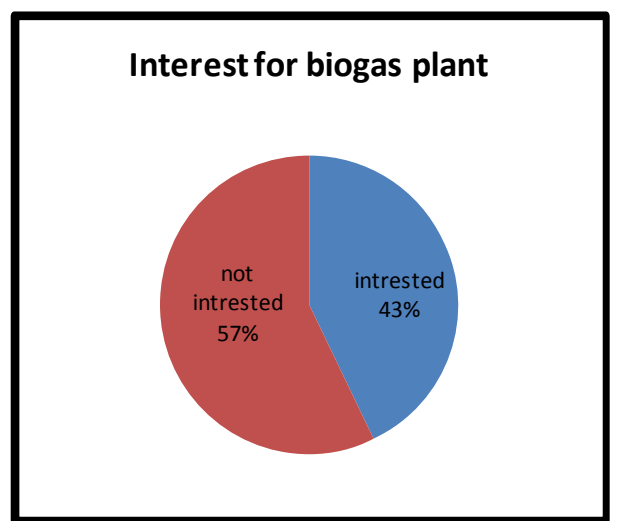

\section{Conclusions}

1. The average consumption of LPG per family is $7.27 \mathrm{~kg} /$ month. Total LPG gas cylinders required per family in rural area is 6.09774 approximately equal to 6 per year. Hence the decision taken by the Central Govt. of India to provide 6 gas cylinders in the subsidy to rural households is correct. Per capita fuel consumption of LPG in adult group for male is $0.2817 \mathrm{Kg}$ and female is $0.1884 \mathrm{Kg}$.

2. In the villages of the district most of the households prefer to use wood as a domestic fuel for cooking and boiling water i.e. main source of energy is wood for domestic purpose. The average consumption of wood for those families who purchase wood is $509.47 \mathrm{~kg}$ per family per month. Hence there is impact on environment due to deforestation.

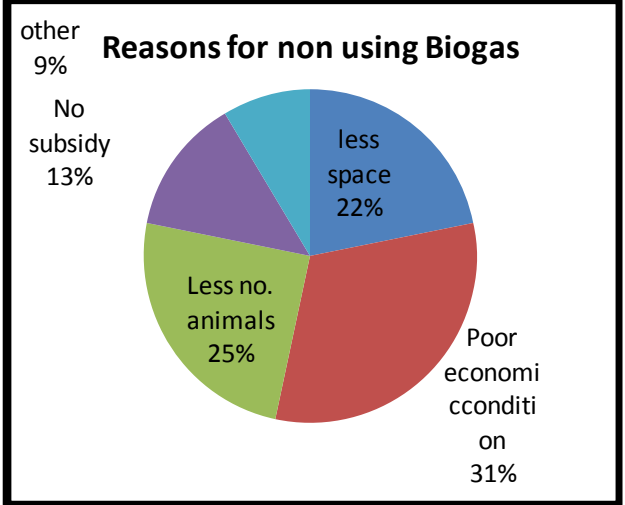

3. The average consumption of Kerosene per family is $3.47 \mathrm{lit} / \mathrm{month}$. The scheme of distribution of Kerosene by the Govt. provides 3lit/month to households is also supported by this study.

4. It is concluded from study that consumption of LPG in Kitchen by households is proportional to the income while tendency to use Kerosene in Kitchen by households, on an average, is almost same for different income groups.

5. Though, due to small sample size, we can't get sufficient observations on electricity, solar and biogas for domestic purpose; the numbers of families which are aware with the biogas development program are considerably less. Also the solar instruments 
are less used for domestic purpose. Hence government has to reschedule the schemes and program of promoting awareness about the Biogas and Solar equipments so that maximum number of families gets benefited.

\section{Acknowledgement:}

It gives me a great pleasure to express my sincere thanks with deep sense of gratitude to Prin. Abhykumar Salunkhe, Chairman and Prin. Mrs. Shubhangi Gawade, Secretary, Shri Swami Vivekanand Shikshn Sanstha, Kolhapur for their constant encouragement for research work and providing advanced facilities in the Department of Statistics in the college.

\section{References:}

1. Central Statistics Office, National Statistical Orgnization, Ministry of Statistics and Programme
2. Implementation Govt. of India, Energy Statistics-2013.

3. Central Statistics Office, National Statistical Orgnization, Ministry of Statistics and Programme Implementation Govt. of India, Energy Statistics-2015.

4. Muhammad A. Foysal: Household energy consumption pattern in rural areas of Bangladesh. Indian Journal of Eneargy, 2012, Vol. 1(5) 72-85.

5. Rajesh Shukla: Pattern of domestic fuel consumption. The Economic Times; 26 Oct. 2009.

6. Statistical Methods- J.Medhi.

7. Software-SAS (Statistical Analysis System). 